\author{
Available online at Dakwah: Jurnal Kajian Dakwah dan Kemasyarakatan \\ http://journal.uinjkt.ac.id/index.php/dakwah \\ Dakwah: Jurnal Kajian Dakwah dan Kemasyarakatan, 25 (2), 2021, 194-208
}

\title{
Pemberdayaan Perempuan Kiprah Muslimat NU
}

\author{
Abdul Hafiz \\ UIN Syarif Hidayatullah Jakarta \\ 7ahafiz@gmail.com \\ Muh. Sungaidi \\ UIN Syarif Hidayatullah Jakarta \\ muhammad.sungaidi@uinjkt.ac.id
}

\begin{abstract}
Muslimat NU is one of the large and strategic non-political women's organizations for Indonesia. This organization is determined to improve the quality of Indonesian women who are smart, skilled, and competitive, uniting the movement of Indonesian women, especially Muslim women of Ahlusunnah Waljama'ah. This organization is mostly engaged in social, education, and da'wah. This paper will examine the movement and contribution of Muslimat with all its roles, achievements and contributions for women with various potentials and social actions.
\end{abstract}

Keywords: NU Muslimat, tradition, modernization and civilization

Abstrak:

Muslimat NU adalah salah satu organisasi wanita non-politik yang besar dan strategis bagi Indonesia. Organisasi ini bertekad untuk meningkatkan kualitas perempuan Indonesia yang cerdas, terampil, dan kompetitif, mempersatukan gerak kaum perempuan Indonesia khususnya perempuan Islam Ahlusunnah Waljama'ah. Organisasi ini banyak bergerak di bidang sosial, pendidikan, dan dakwah. Tulisan ini akan mengkaji gerakan dan kontribusi Muslimat dengan segala peran, kiprah dan kontribusinya bagi wanita dengan berbagai potensi dan aksi sosialnya.

Kata kunci:Muslimat NU, tradisi, modernisasi dan peradaban

Permalink/DOI: http://doi.org/10.15408/dakwah.v25i2.23238

\section{Pendahuluan}

Islam yang diajarkan Rasulullah

telah membawa perubahan-perubahan

besar dalam kehidupan dan sejarah

kaum wanita. Dalam pembinaan dan membentuk umat (komunitas) dan kelembagaannya Nabi Muhammad SAW telah mengangkat harkat dan derajat wanita sebagai makhluk Allah yang 
sangat mulia hingga masyarakat lebih berperadaban dan memiliki intergritas dan kinerja.

Kajian gerakan wanita Islam Indonesia yang membahas gerakan tersebut bergerak beriringan dengan sosial movement lainnya masih sangat terbatas. Baik itu dalam kajian konteks waktu, aspek pemikir pergerakan wanita per periode, $\backslash$

hingga bagaimana sebuah gerakan wanita di kalangan elit terpelajar sebagian Nahdlatul Ulama (NU). ${ }^{1}$

Sejarah mencatat bahwa kongres NU di Menes tahun 1938 itu merupakan forum yang memiliki arti tersendiri bagi proses katalisis terbentuknya organisasi Muslimat NU. ${ }^{2}$ Dalam kongres Kongres NU XV di Surabaya tahun 1940.tampil seorang muslimat NU di atas podium, berbicara tentang perlunya wanita $\mathrm{NU}$ untuk mendapatkan hak yang sama dengan kaum lelaki dalam menerima didikan agama melalui organisasi NU. 3

Ruang gerak wanita cukup di rumah dan domestik kuat melekat pada umumnya warga NU saat itu.Namun dinamika terus berlangsung hingga terjadi polarisasi pendapat yang cukup hangat tentang perlu tidaknya wanita berkecimpung di dalam pblik dan di dalam organisasi. 4

Sejak kongres NU di Menes, wanita telah secara resmi diterima menjadi anggota NU meskipun sifat keanggotannya hanya sebagai pendengar dan pengikut saja, tanpa diperbolehkan menduduki kursi kepengurusan.Hal seperti itu terus berlangsung hingga Kongres NU XV di Surabaya tahun 1940.Dalam kongres tersebut terjadi pembahasan yang cukup sengit tentang usulan Muslimat yang hendak menjadi bagian tersendiri, mempunyai kepengurusan tersendiri dalam tubuh NU.

\section{Sejarah Muslimat NU}

Dalam kajian konteks waktu, aspek pemikir dan pergerakan wanita per periode, bagaimana sebuah gerakan wanita saling mempengaruhi, mensinergi dan memberi kontribusi kepada nusa, bangsa dan Negara dengan Islam sebagai dasar gerakan. 5

Sejarah muslimat NU merupakan bagian yang tidak bisa dipisahkan dengan sejarah NU dan sejarah perjuangan bangsa.Muslimat dilahirkan oleh NU senantiasa untuk mengabdi kepada agama bangsa dan Negara dan menselaraskan kiprah perjuangannya sejalan dengan perkembangan zaman.

Rintisan ini diawali dari berbagai aktifitas ibu - ibu dan istri tokoh NU serta ibu - ibu nyai yang melibatkan diri dalam setiap muktamar ke muktamar NU yang selalu tampil sebagai pendengar dan membantu aktifitas dalam muktamar.Pada masa itu sangat sulit menampilkan kaum perempuan di ranah public.Perdebatan ulama tentang perlu tidaknya gerakan perempuan dalam sebuah organisasi memerlukan waktu yang panjang hingga terjadi polarisasi pendapat cukup hangat dalam pembahasan dimuktamar.

Pada th 1938 muncul ide, bahwa perlunya sebuah wadah organisasi wanita NU, pada masa itu tampillah tokoh perempuan dari jawa barat ibu $\mathrm{Hj}$. R. Djuwaisih yang pertama kali 
berpidato di forum muktamar NU ke 13 di Banten. Kemudian disosialisasikan lebih intensif dan di teruskan gagasan ini pada muslimat ke 14 di magelang, dilanjutkan pada muktamar ke 15 di Surabaya. Selama kurun waktu tersebut keberadaan muslimat masih bersetatus sebagai bagian dari NU dengan nama NOM.

Berkat wawasan yang luas dan pandangan yang moderat dari khadrotu syeh KH.Hasyim Asari dan KH.Wahab Hasbullah bahwa perlunya sebuah organisasi perempuan muslimat yang mengatur kaum perempuan di lingkungan NU. Dengan melihat kegigihan para wanita - wanita NU, maka akhirnya direstui berdirinya organisasi muslimat NU pada tgl 29 Maret 1946/ 26 Robiul akhir 1365 H di purwokerto bertepatan pada muktamar NU ke 16 dengan nama NOM (Nahdlatul Oelama' Muslimat) ${ }^{6}$ dan pada saat itu ditetapkan sebagai harlah muslimat dengan pernyataan " Dengan Wadah Perjuangan Muslimat NU Wanita Islam Ahlussunah Wal Jamaah mengabdi kepada Agama Bangsa dan Negara." Berdirinya muslimat ini tidak lepas dari dorongan semangat dari Bpk KH.Dahlan dan bpk.A. Aziz Dijar sebagai ketua telah dipilih Khadijah Dahlan dari pasuruan istri Bpk. Dahlan.

Pernyataan penerimaan Muslimat untuk ditandatangani Hadlratus Syaikh KH.Hasyim Asy'ari dan KH. A. Wahab Hasbullah. Dengan adanya secarik kertas sebagai tanda persetujuan kedua tokoh besar NU itu, proses penerimaan dapat berjalan dengan lancar.A. Aziz Dijar dan Dahlan terlibat secara penuh dalam penyusunan peraturan khusus yang menjadi cikal bakal Anggaran Dasar dan Anggaran Rumah Tangga Muslimat NU di kemudian hari.Bersamaan dengan hari penutupan kongres NU XVI, organisasi Muslimat NU secara resmi dibentuk, tepatnya tanggal 29 Maret 1946 / 26 Rabiul Akhir 1365. Pada tanggal 29 Maret 1946 telah diresmikan adanya bagian wanita dalam NU dengan nama NU Muslimat.7

Mengikutsertakan wanita dalam dalam organisasi guna untuk mengangkat

derajat wanita, karena pada waktu itu pengetahuan wanita memang sangat memprihatinkan.Dengan status otonomi ini Muslimat ini Muslimat mengatur dan melaksanakan kegiatan-kegiatan yang bertujuan meningkatkan peranan organisasi dalam membina para anggotanya dan menggiatkan organisasi dalam pengabdiannya kepada negara.Muslimat NU kemudian masuk menjadi anggota Kowani pada tahun 1956. Pada th 1956 Muslimat membangun perwakilan di 5 propinsi bergabung dalam KOWANI (Korp Wanita Indonesia ) Muslimat menempati posisi yang setrategis. Pada th 1968 bergabung dengan KNKWI (Komite Nasional Kedudukan Wanita Indonesia). Pada th 1967 muslimat mewakilkan ibu Hj. Mahmudah Mawardi membentuk BMOIWI (Badan Musyawarah Organisasi Islam Wanita Indonesia).

Di masa era Orde Lama 19451965 muslimat mengikut sertakan badan - badannya dipusat maupun di daerah daerah mengikuti pelatihan - pelatihan kader revolusi.Th 1964 muslimat 
menyelenggarakan latihan kader sukarelawati yang dilatih kemiliteran dilapangan Cibubur, mempergunakan senjata, bongkar pasang senjata, dapur umum, PPPK, penanggulangan kebakaran, persatuan baris berbaris/ PBB, dll.Pengkaderan dibekali dengan gemblengan fisik dan mental dalam jiwa dan raga oleh tokoh - tokoh spiritual sebagai persiapan perlawanan terhadap gerwani (gerakan wanita tani/ PKI).

Muslimat unjuk kebolehan memimpin pawai drumband dipimpin oleh ibu Syaifudin Zuhri ke istana Negara sebagai respon kegiatan terhadap pihak lain. Kerjasama muslimat dengan pihak militer telah dibangun sejak th 1958 1960 dengan KKS wanita militer yang diwakili ibu Hj. Sholihah Wahid hasyim dan dilanjutkan oleh ibu Malihah agus th $1960-1962$.

Ketika PKI meletus pada puncaknya 30 september 1965, muslimat membuat berbagai aksi dan pernyataan: 2 Oktober 1965 PP Muslimat diwakili ibu Sholikhah Wahid Hasyim membuat pernyataan mengutuk pelaku - pelaku PKI sebagai penghianat agama bangsa dan Negara. 5 Oktober 1965 dalam From Pancasila muslimat membuat pernyataan mengutuk PKI sebagai penghianat agama bangsa dan Negara.19 oktober 1965 muslimat melalui KOWANI minta pada Dep P\&K agar membubarkan taman kanak - kanak " Melati " milik gerwani. 8 November 1965 perempuan yang tergabung dalam fron pancasila seksi wanita yang dipimpin oleh Ibu Asmah Syahroni menuntut perbubaran PKI beserta underbownya.Kebijakan Penting di awal Orde Baru \& Masa Pembangunan.

Pada th 1968 muslimat NU menyepakati dan menyetujui peogram keluarga berencana yang dilaksanakan oleh BKKBN. Di masa pembangunan muslimat disamping melaksanakan program internal, juga banyak berperan membantu program pemerintah baik dipusat maupun di daerah, antara lain bidang kesehatan, sukses keluarga berencana, lingkungan hidup dan peningkatan peranan wanita.

Dengan status otonomi ini muslimat dapat mengatur dan melaksanakan kegiatan yang bretujuan untuk meningkatkan peranan organisasi dalam membina para anggotanya dan mengabdi pada negara. Tujuan dari perjuangan organisasi ini adalah melaksanakan program NU dikalangan wanita, membawa wanita Islamkearah kesadaran beragama, berbangsa, dan bernegara, serta sadar akan hak dan kewajibannya menurut hukum.

\section{Muslimat Dinamika Modern}

Arus globalisasi dan derasnya kemajuan teknologi komunikasi telah memperlihatkan perkembangan yang menakjubkan disatu sisi, namun disisi lain masyarakat nampaknya mulai berhadapan pada benturan budaya, seolah-olah perlahan-lahan ilmu pengetahuan mengucapkan selamat tinggal pada agama, kehidupan manusia semakin kering akan makna spiritual. Nahdlatul Ulama adalah ciri dari sebuah komunitas Islam moderat, pluralis dan akomodatif. 
Keorganisasian Muslimat sama dengan keorganisasian NU yaitu berpegang teguh kepada doktrin toleransi, akomodatif dan berupaya memperjuangkan tradisi pemahaman dan pengamalan ajaran Islam yang sesuai dengan kultur Indonesia. Dengan kata lain NU menetapkan diri sebagai pengawal tradisi dengan mempertahankan faham Ahlusunnah Wal Jama'ah. ${ }^{8}$

Dalam setiap periode muncul wacana atau agenda baru dalam gerakan perempuan.Wacana baru itu dipengaruhi oleh banyak faktor yang umumnya merupakan respon terhadap perubahan kebijakan dan perkembangan aktual peristiwa-peristiwa politik, ekonomi, sosial, dan budaya. Dari waktu kewaktu gerakan perempuan meluas tidak hanya wacana yang mempermasalahkan seperti poligami, perkawinan sederajat, kesetaraan, KDRT dan agenda perempuan lain tetapi juga masalahmasalah umum seperti demokrasi, nasionalisme, HAM, hingga masalah lingkungan hidup.

Dalam menekan masalah perkawinan dibawah umur muslimat ikut berperan dalam pembentukan $\mathrm{BP}_{4}$ pada th 1952. (Badan Penasehat dan Perkawinan dan Penyelesaian Perceraian).Bersamaan dengan konggresnya yang ke 2 Muslimat dalam program bidang pendidikan menyelenggarakan kursus kader kepemimpinan NUM dan pembentukan komisariat daerah (KORDA : Kordinator Daerah) yang mengkordinir cabang cabang di daerah pembantu gubernur atau X karisedinan. Dalam konggresnya yang ke 3, ketika kondisi masyarakat banyak yang buta huruf maka muslimat memprogramkan kegiatan pemberantasan buta huruf.Dalam bidang social muslimat memprogramkan kegiatan pertolongan kepada anak anak yatim dan janda - janda terlantar.

Kiprah organisasi wanita Islam dalam buku ini adalah contoh kiprah beberapa organisasi wanita dalam pembangunan di Indonesia.Organisasiorganisasi wanita Islam ini mengantisipasi kegiatan pembangunan sesuai dengan kondisi dan potensi masing-masing. Ada yang menonjol dalam satu bidang, kurang di bidang lain. Dinilai dari tolak ukur jender, semua kegiatan pembangunan yang sudah dilaksanakan beberapa organisasi wanita Islam ini baru mencapai tingkat akses dan belum mencapai tingkat kekuasan. Namun apa yang sudah dicapai tersebut kemudian memberikan dampak positif bagi wanita, terutama dalam meningkatkan peranannya disatu pihak dan mengambil manfaatnya di pihak lain sesuai dengan kebijakan pemerintah dalam upaya mengintegerasikan wanita dalam pembangunan. Pengemban programnya dalam pembangunan yang akan datang diharapkan dapat lebih menempatkan kemampuan wanita dan merespon program pemerintah, khususnya yang berkaitan langsung dengan kehidupan wanita dan keluarga. ${ }^{9}$

Untuk mencapai visi dan misi yang dimaksudkan muslimat menentukan strategi seperti di bawah ini; ${ }^{10}$ 
1. Mempersatukan gerak perempuan Indonesia, khususnya Perempuan Ahlusunnah Wal Jama'ah.

2. Meningkatkan kualitas perempuan indonesia yang cerdas, trampil, dan kompetitif, sebagai bentuk tanggung jawab terhadap agama, bangsa, negara dan membentuk generasi penerus bangsa yang taat beragama.

3. Bergerak aktif dalam kegiatana pelayanan masyarakat di bidang:

a. Peribadatan, dakwah, dan penerangan

b. Sosial, ekonomi, kesehatan, dan lingkungan hidup

c. Pendidikan

d. Hukum dan advokasi

e. Usaha kemasyaraatan lainnya yang tidak bertentangan dengan organisasi.

4.Meningkatkan jejaring dan kerjasama dengan badan-badan lembaga/organisasi yang tidak bertentangan dengan visi dan isi organisasi.

Kegiatan-kegiatan yang dilakukan oleh Muslimat NU dibagi dalam Pendidikan, Da'wah dan Sosial Kemasyarakatan. Muslimat NU telah mengiringi perjalanan bangsa pada era Reformasi, khususnya pada era Demokrasi (prosedural) menuju demokrasi (substantif). Disebut demokrasi prosedural karena proses demokrasi di Indonesia sudah berada pada sistem dan mekanisme demokrasi yang sudah terlembagakan. Ada KPU, KPUD, Panwas, ada Lembaga Yudisial yang terdiri atas MA dan MK, ada lembaga eksekutif dan legislatif. Tetapi secara substantif masih ditemukan ketidakadilan dan ketidakjujuran terhadap pelaksanaan kedaulatan rakyat, penegakan hukum, pemberantasan korupsi dan sebagainnya.

Sesuai dengan keberadaannya sebagai eksponen perempuan dan bagian dari civil society yang memiliki jumlah anggota lebih dari 12 juta yang tersebar di seluruh Indonesia, organisasi ini memiliki 33 wilayah, 516 cabang di tingkat kabupaten/kota, 4.750 anak cabang di tingkatan kecamatan serta lebih 26 ribuan ranting di tingkatan desa atau kelurahan. Beberapa cabang sudah mengembangkan di tingkat anak ranting. Dalam mewujudkan tujuannya, Muslimat NU telah membina kurang lebih 9.80o taman kanak-kanak dan Roudhotul Athfal, 14.350. taman pendidikan al-Quran dan 4.600 pendidikan anak usia dini, 103 pusat pelayanan kesehatan, 106 panti asuhan, 10 asrama putri, 10 panti jompo, 59.956 majlis ta'lim, koperasi an-nisa yang sudah berbadan hukum terdiri dari 1 induk koperasi, 9 koperasi sekunder, 162 koperasi primer yang berbadan hukum, 355 TPK (tempat pelayanan koperasi), 146 kelompok bimbingan ibadah haji (KBIH) dan 8 balai latihan kerja (BLK). ${ }^{11}$

\section{Muslimat dan Amanat Publik}

Sejarah pergerakan wanita NU memiliki akar kesejarahan panjang dengan pergunulan yang amat sengit yang akhirnya memunculkan berbagai gerakan wanita baik Muslimat, Fatayat hingga Ikatan Pelajar Putri NU. Dalam kongres NU di Menes tahun 1938 itu merupakan forum yang memiliki arti tersendiri bagi proses katalisis 
terbentuknya organisasi Muslimat NU. Sebuah rintisan yang sangat berharga dalam memperjuangkan harkat dan martabat kaumnya di lingkungan NU, sehingga keberadaannya diakui dunia internasional, terutama dalam kepeloporannya di bidang gerakan wanita. $^{12}$

- Ketua Muslimat Chadidjah Dahlan merupakan salah seorang wanita di lingkungan NU itu selama dua tahun yakni sampai Oktober 1948.Sebuah rintisan berharga dalam memperjuangkan harkat dan martabat kaumnya di lingkungan NU, sehingga keberadaannya diakui dunia internasional, terutama dalam kepeloporannya di bidang gerakan wanita. ${ }^{13}$

Muslimat NU, tahun ini cukup banyak teman-teman yang sukses dalam Pilkada. Kader Muslimat NU yang sukses di Pilkada, selain Khofifah, yakni Nyai Hj Munjidah Wahab (bupati Jombang terpilih), Dra $\mathrm{Hj}$ Umi Azizah (bupati Tegal terpilih), Hj Ita Puspita Sari (wali kota Mojokerto terpilih), $\mathrm{Hj}$ Ana Mu'awanah (bupati Bojonegoro terpilih) serta Hj Lilik Muhibah MpdI (wakil wali kota Kediri terpilih bisa menjalankan amanat masyarakat di masing-masing wilayah dengan baik. ${ }^{14} \mathrm{Di}$ level kabupaten/kota memunculkan fenomena The Power of Emak-emak Khofifah terpilih sebagai gubernur Jawa Timur periode 2019-2024 dan keberhasilan kader Muslimat NU di Pilkada serentak 2018.15

\section{Muslimat NU dan Masa Depan}

Dalam tulisan ini menggunakan ilmu sosial sebagai pendekatannya yaitu karena kajiannya mencangkup golongan sosial yang berperan, peranan dan status sosial dan sebagainnya.Durkheim mengutamakan arti penting masyarakat struktur, interaksi dan istitusi sosial dalam memahami pemikiran dan perilaku manusia.Hal ini dapat dicermati dari penekanan hampir seluruh perubahan utama manusia yaitu persoalan hukum, moralitas, profesi, keluarga dan kepribadian, ilmu pengetahuan, seni dan juga agama dengan menggunakan sudut pandang sosial. Durkheim mengklaim bahwa tanpa adanya masyarakat yang melahirkan dan membentuk semua itu, maka tak ada satupun yang akan muncul dalam kehidupan. Durkheim berharap untuk memperlihatkan bagaimana sebuah konsensus sosial baru dapat menciptakan kembali nilai-nilai komunitas dan tatanan sosial, tanpa mengorbankan emansipasi manusia yang berasal dari keambrukan feodalisme.

Perjalanan menuju tegaknya tujuan tidak bisa dilepaskan dari visi dan misi dari organisasi tersebut sehingga mampu melewati perkembangan sosial dan politik di Indonesia.

Kini muslimat NU telah mewadahi 13568 TPQ, 980o TK/RA, 4657 Play Group, 38000 majlis ta'lim, 103 panti asuan, 74 BKIA/ Rumah bersalin / Rumah sakit, 11 balai latihan kerja, $146 \mathrm{KBIH}, 9$ pusat koprasi, 131 koprasi primer dan outlet pemasaran sector agro dan 17 rintisan PKBM majlis ta'lim, 29 rintisan berbasis wirausaha dan simpan pinjam, 79 rintisan program 
life skiil untuk anak putus sekolah dan mereka yang berada pada usia produktif.

Muslimat memberikan layanan yang bersifat institusional permanent dalam mengejar pencapaian tarjet tujuan pembangunan Millennium Development Gools, juga melakukan berbagai program dengan MOU dengan pemerintah terkait dengan berbagai kementrian.

Kini pada usianya yang ke 67 muslimat NU telah memiliki catatan sejarah yang panjang dan telah terbukti oleh sejarah bahwa muslimat begitu indah dan lihai dalam memainkan peranannya dalam berjuang membangun masyarakat.Sejarah muslimat NU merupakan bagian yang tidak bisa dipisahkan dengan sejarah NU dan sejarah perjuangan bangsa.Muslimat dilahirkan oleh NU senantiasa untuk mengabdi kepada agama bangsa dan Negara dan menselaraskan kiprah perjuangannya sejalan dengan perkembangan jaman.

\section{Muslimat dana Organisasi Perempuan}

Muslimat dalam usianya yang ke 67 muslimat NU telah memiliki catatan sejarah yang panjang dan telah terbukti oleh sejarah bahwa muslimat begitu indah dan lihai dalam memainkan peranannya dalam berjuang membangun masyarakat.

Dalam Kongres Ke-17 Muslimat NU ini, Khofifah dipilih secara aklamasi oleh 34 pengurus wilayah, 525 pengurus cabang, dan 4 pengurus cabang istimewa (Hongkong, Arab Saudi, Malaysia, dan Sudan) yang memiliki hak suara dalam kongres. Dengan demikian, perempuan kelahiran Surabaya 51 tahun lalu ini memegang pucuk pimpinan Muslimat NU selama 4 periode (2000-2021). ${ }^{16}$

Dalam Kongres Ke-17 Muslimat NU ini, Khofifah dipilih secara aklamasi oleh 34 pengurus wilayah, 525 pengurus cabang, dan 4 pengurus cabang istimewa (Hongkong, Arab Saudi, Malaysia, dan Sudan) yang memiliki hak suara dalam kongres. Dalam Kongres Ke-17 Muslimat NU ini, Khofifah dipilih secara aklamasi oleh 34 pengurus wilayah, 525 pengurus cabang, dan 4 pengurus cabang istimewa (Hongkong, Arab Saudi, Malaysia, dan Sudan) yang memiliki hak suara dalam kongres. Dengan demikian, perempuan kelahiran Surabaya 51 tahun lalu ini memegang pucuk pimpinan Muslimat NU selama 4 periode (2000-2021).

Sejalan dengan perkembangan jaman hingga th 1984 dimana NU melaksanakan muktamar di situbondo memutuskan bahwa NU kembali ke khitoh 1926, maka muslimat lebih leluasa dalam pengabdiannya sebagai organisasi social keagamaan, sedangkan aspirasi politik warga NU di salurkan melalui berbagai parpol yang diwakili oleh kader NU dan tokoh - tokoh NU di berbagai parpol. Berbagai peran dan kontribusi Produk-produk Hasil Olahan Sampah BLK Muslimat NU. ${ }^{17}$

Balai Latihan Kerja BLK Muslimat Nahdlatul Ulama membentuk paguyuban bank sampah berbasis masyarakat.Lewat bank sampah, mereka mendaur ulang dan memanfaatkan sampah untuk dijadikan berbagai macam produk keterampilan bernilai ekonomis dan membantu wanita di berbagai lapisan masyarakat luas. 
Balai Latihan Kerja BLK Muslimat Nahdlatul Ulama membentuk paguyuban bank sampah berbasis masyarakat.Lewat bank sampah, mereka mendaur ulang dan memanfaatkan sampah untuk dijadikan berbagai macam produk keterampilan bernilai ekonomis. ${ }^{18}$

\section{Muslimat NU Sebagai Gerakan Perempuan}

Salah satu organisasi keagamaan terbesar di Indonesia Nahdlatul Ulama (NU) yang lahir pada tanggal 31 Januari 1926 merupakan organisasi yang pada mulanya hanya beranggotakan kaum laki-laki. Melihat fenomena ini $\mathrm{Ny}$. Djunaisih sebagai perintis organisasi Muslimat NU memiliki gagasan bahwa, "Dalam agama Islam tidak hanya lakilaki saja yang harus dididik berkenaan dengan ilmu agama melainkan perempuan juga harus dan wajib mendapat didikan yang selaras dengan tuntutan dan kehendak agama Islam" (Afif 11).Gagasan tersebut disampaikan dalam pidatonya dalam Kongres NU ke13 di Menes Banten tahun 1938 yang menjadi cikal bakal lahirnya Muslimat NU (Ma'shum dan Ali Zawawi 110).Meskipun gerakan yang diprakarsai ini sarat dengan pengaruh tradisi dan budaya patriarki namun kaum perempuan pada masa itu berhasil bangkit dan menyuarakan pentingnya perempuan berorganisasi dan berperan aktif tidak hanya di wilayah domestik.

Dalam momentum yang sama hadir pula Ny. Siti Syarah sebagai pembicara kedua yang turut mendukung pendapat Ny.Djunaisih dalam isi pidatonya. Sehingga, kedua tokoh tersebut memiliki peran besar terhadap berdirinya Muslimat NU pada rentang waktu 1938-1952 yang sampai sekarang menjadi salah satu badan otonom dalam tubuh organisasi NU. Organisasi Muslimat NU kemudian memprakarsai lahirnya Fatayat NU sebagai organisasi pemudi Islam yang keduanya memiliki hubungan seperti saudara kakak dan adik dengan segala suka dan duka persaudaraan.

Tampilnya kedua perempuan dalam acara Kongres NU ke-13 di Menes, Banten ini didukung oleh keputusan fatwa Bahtsul Masa'il ad-Diniyah pada tahun 1935, bahwa seorang perempuan yang berdiri di tengah-tengah laki-laki lain itu haram hukumnya, kecuali jika bisa "sunyi" (terhindar) dari larangan agama Islam, seperti dapat menutup auratnya dan selamat dari segala fitnah, maka hukumnya boleh (jaiz). Hal ini karena suara perempuan tidak termasuk aurat, menurut pendapat yang ashhah.Keputusan tersebut berdasarkan landasan dari kitab Ittihaf al-saddah alMuttaqin, Syarah al-Sittin, al Fawa alKubra al-Fiqhiyah (Asrori \& Muntaha 157).

Muslimat NU pada mulanya bernama NOM (Nahdlatoel Oelama Moeslimat) yang kemudian menyelenggarakan rapat umum NOM pada Kongres NU ke-14 tahun 1939 di Magelang.Pada kesempatan ini dihadiri oleh enam perempuan NU dari sejumlah wakil daerah untuk menyampaikan gagasan-gagasannya. Mereka adalah Ny. Saodah dan Ny. Gan Antang keduanya dari Bandung, Ny. Badriyah dari 
Wonosobo, Ny. Sulimah dari Banyumas, $\mathrm{Ny}$. Istiqomah dari Parakan dan $\mathrm{Ny}$. Alfiyah dari Kroya Cilacap.Inti dari pidato yang disampaikan oleh perempuan-perempuan NU tersebut adalah diperlukan adanya pergaulan di dalam perkumpulan untuk mendukung tugas penting para perempuan, karena mereka memegang peran penting dalam mencerdaskan bangsa.Oleh sebab itu, diperlukan membentuk organisasi perempuan di dalam Organisasi Islam Tradisional.

Selanjutnya pada Kongres NU ke15 tahun 1940 di Surabaya diadakan rapat tertutup yang dipimpin oleh $\mathrm{Ny}$. Djunaisih dan Siti Hasanah sebagai penulisnya. Perundingan tersebut menghasilkan keputusan: pengesahan NOM oleh NU, pengesaahan Anggaran Dasar NOM oleh Kongres NU, adanya Pengurus Besar NOM, menetapkan daftar pelajaran untuk tingkat Madrasah Banat, rencana menerbitkan majalah NOM, bertamasya keliling kota Surabaya pada hari Kamis 12 Desember 1940 (Zuhri 44-45). Rekam jejak perjalanan ini belum selesai karena pada Kongres NU ke-16 di Purwokerto tahun 1946 disahkan secara resmi lahirnya NOM dengan nama Nahdlatul Ulama Muslimat (NUM) sebagai organisasi perempuan di bawah naungan NU. Diterimanya NOM oleh PBNU ini tidak terlepas dari dukungan sebagian tokoh NU yang saat itu memiliki pemikiran bahwa sudah sampai pada tahap diperlukannya kehadiran perempuan dalam perjuangan dan organisasi, agar paham Ahlus Sunnah Wal Jama'ah sebagai paham keagamaan NU dapat diterima merata antara laki-laki dan perempuan.

Kemudian pada kongres NU ke19 di Palembang tahun 1952, NUM menjadi badan otonom NU dan mengubah namanya menjadi Muslimat NU yang dikenal secara luas sampai saat ini (Zuhri 81).Muslimat NU merupakan organisasi yang berasas Islam dan berideologi menurut paham Ahlus Sunah Wal Jama'ah bahwa Negara Kesatuan Republik Indonesia (NKRI) didirikan oleh seluruh rakyat Indonesia.Latar belakang terbentuknya Muslimat NU ini tidak terlepas dari keadaan sosial, pendidikan, ekonomi dan politik masyarakat dalam menempatkan perempuan pada posisi yang serba tidak menguntungkan pada saat itu. Kedua tokoh perempuan progresif Ny. Djunaisih dan Ny. Siti Syarah inilah yang kemudian memperjuangkan hak-hak kaum perempuan agar memiliki kesempatan berpendidikan yang sama seperti laki-laki pada umumnya. Kaum perempuan tidak hanya terjebak dalam kesibukan-kesibukan pekerjaan domestik tetapi juga secara alamiah mereka memiliki ruang untuk mengembangkan potensi, bakat dan minat yang dimiliki di ranah yang lebih luas yakni publik.

Istilah konco wingking yang tersemat pada kaum perempuan saat itu justru menjadikan kaum perempuan tidak mendapatkan akses yang sama untuk aktif dalam kegiatan di luar rumah. Mereka hanya diarahkan berfokus pada kegiatan-kegiatan monoton setiap harinya sebagai ibu yang dipenuhi dengan kegiatan-kegiatan 
rumah tangga seperti memasak, mencuci pakaian, mengurus anak, membersihkan rumah, mengurus suami. Satu sisi kebanyakan kaum perempuan memang merasa nyaman dengan posisi sesuai konsep 'ibuisme' yang diterapkan oleh rezim Suharto ini. Mereka secara terangterangan tidak menyadari bahwa hal demikian justru akan membawa banyak kemunduran jika tidak diimbangi dengan proses belajar secara terus-menerus untuk mengembangkan keilmuan yang telah mereka miliki.

Sebagai akibatnya, kaum perempuan pada saat itu memang sangat menggantungkan segala aspek kehidupannya pada kaum laki-laki. Dalam menentukan suara pun kaum perempuan tidak memperoleh hak untuk berpendapat meskipun di dalam rumah sendiri. Semua keputusan hanya berhak diputuskan oleh kepala keluarga, suami yang memegang hak penuh dalam menentukan urusan-urusan berkeluarga. Apakah suami dalam hal ini termasuk dalam kategori amanah atau tidak hal ini menjadi urusan nomor sekian, karena pada dasarnya istri akan selalu ditempatkan mengikuti suami dari belakang istilah dalam bahasa Jawa: suwargo nunut neroko katut. Ironis, bagaimana bisa kaum perempuan akan berkembang lebih mandiri jika mereka terkungkung dalam budaya patriarki yang justru mereka anggap sebagai hal yang menyenangkan karena merasa hidupnya sudah 'ditanggung' sepenuhnya oleh kaum laki-laki.

Selain itu, dalam aspek mendapatkan hak berpendidikan kaum perempuan tidak diprioritaskan.Apalagi jika memang mereka terlahir dan besar dalam keluarga menengah ke bawah. Bisa dipastikan bahwa anak laki-laki akan mendapatkan lebih banyak dukungan mendapatkan kesempatan berpendidikan karena dianggap lebih mampu dalam mengenyam pendidikan baik formal maupaun nonformal. Mereka diarahkan untuk menjadi pemimpin masa depan sedangkan akses kaum perempuan dipangkas begitu saja untuk dikondisikan menjadi orang rumahan yang tidak tahu dunia luar. Kehidupan kaum perempuan hanya sebatas dapur, kasur dan sumur. Dalam sejarahnya, pesantren yang pertama kali menerima santri-santri perempuan adalah Mamba'ul Ma'arif di Denanyar Jombang pada tahun 1921 yang sebelumnya hanya menerima santri-santri laki-laki pada tahun 1917 dan menyelenggarakan pendidikan bagi laki-laki.

Keadaan-keadaan perempuan seperti ini kemudian juga diperparah dengan beberapa hal pelik yang dialami oleh kaum perempuan.Pernikahan R.A Kartini anak dari seorang bangsawan Bupati Rembang dalam bukunya Habis Gelap Terbitlah Terang.Dia dipaksa kawin dengan suami yang telah beristri dan dilarang melanjutkan sekolahnya ke Belanda. Dalam sumber literasi lain Sukarno pada karyanya Sarinah 'mendewi tololkan' istrinya sebagai mutiara yang selalu ditolong sampai mati dan tidak pernah menjadi akil baligh (Sukarno 9). Kompleksitas masalah yang dialami kaum perempuan tidak hanya dirasakan oleh kaum menengah ke bawah.Dua tokoh tersebut secara jelas menggambarkan bagaimana posisi kaum 
perempuan yang sangat tidak bisa terbebas dari kontrol dan kekuasaan laki-laki dalam segala aspek kehidupan mereka meskipun mereka hidup di keluarga bangsawan.Kondisi perempuan dalam tubuh organisasi Nahdlatul Ulama (NU) telah termanifestasi dalam pergerakan perempuan yang diwadahi oleh Muslimat NU. Sepanjang proses kelahiran organisasi ini telah menunjukkan bahwa latar belakang sosial, ekonomi, pendidikan dan politik dalam masyarakat telah memberi pengaruh yang sangat besar terhadap perubahan arah perjuangan kaum perempuan. Apalagi dalam proses mewujudkan badan otonom Muslimat NU dalam organisasi NU tidak semertamerta hanya terdapat campur tangan kaum perempuan. Namun, peran para kiai yang menunjukkan bahwa keadilan dan kesetaraan gender antara hak dan kewajiban laki-laki dan perempuan hendaknya memang akan terwujud dengan kerjasama diantara kedua belah pihak baik laki-laki maupun perempuan.

Muslimat NU telah merumuskan sejumlah langkah strategis untuk membentuk perempuan Indonesia sejahtera dan religius. Tercapainya visi jangka menengah itu akan berhasil bisa ditunjang beberapa faktor yakni layanan yang berkualitas, jejaring hingga ke akar rumput, infrastruktur TI yang memadai, pendanaan yang menunjang, serta SDM berkualitas.

Meskipun sebagian besar anggota Muslimat NU adalah ibu-ibu setengah senior bahkan ibu senior, tetapi Muslimat NU telah memulai adaptasi dengan TI.Pendaftaran Kongres XVII dilakukan secara daring.Seluruh pengurus cabang se Jawa 100 persen mendaftar online.Dari total peserta 75 persen mendaftar secara online. ID card sudah menggunakan barcode dengan sistem pemindai.Muslimat NU juga tak ingin tertinggal dan mengembangkan layanan keuangan digital dan layana keuangan tanpa kantor untuk keuangan inklusif. ${ }^{19}$

Muslimat NU melihat perlu ada modal keunggulan komparatif yang dimiliki para Muslimah yakni modal sosial, modal persatuan, modal untuk menjadi umat terbaik, modal sosial, dan modal pemikiran.Prinsip sosial yang harus dipegang Muslimat adalah sikap moderat, seimbang, toleransi, dan loyalitas tegak lurus. Pimpinan Cabang adalah pimpinan Muslimat NU ditingkat kabupaten dan kota atau

daerah yang disamakan tingkatanya. Dalam kabupaten atau kota daerah disamakan tingkatannya dapat didirikan satu cabang kecuali secara historis telah terbentuk dari satu cabang atau alasan lain yang telah disahkan oleh PP. Di tiap cabang NU harus didirikan cabang Muslimat NU.

Khofifah mengatakan, Indonesia akan menjadi bangsa besar, mandiri dan kuat, jika jati diri bangsa dijaga dan dikuatkan melalui kedaulatan politik, kedaulatan ekonomi, kedaulatan budaya, dan lebih terpenting lagi adalah kedaulatan pikiran. Masih banyak lagi program yang dilaksanakan oleh muslimat mulai pusat hingga daerah sebagia pengabdian kepada agama bangsa dan Negara. 
Dalam kesempatan itu, Khofifah juga menyampaikan kepada hadirin, ada 536 pengurus cabang Muslimat NU dan 34 pengurus wilayah yang mendaftarkan diri mengikuti Kongres XVII Muslimat NU dengan total peserta 2.144 orang.

Kegiatan-kegiatan yang dilakukan oleh Muslimat NU dibagi dalam Pendidikan, Da'wah dan Sosial Kemasyarakatan.Muslimat NU telah mengiringi perjalanan bangsa pada era Reformasi, khususnya pada era Demokrasi (prosedural) menuju demokrasi (substantif). Disebut demokrasi prosedural karena proses demokrasi di Indonesia sudah berada pada sistem dan mekanisme demokrasi yang sudah terlembagakan. Ada KPU, KPUD, Panwas, ada Lembaga Yudisial yang terdiri atas MA dan MK, ada lembaga eksekutif dan legislatif.Tetapi secara substantif masih ditemukan ketidakadilan dan ketidakjujuran terhadap pelaksanaan kedaulatan rakyat, penegakan hukum, pemberantasan korupsi dan sebagainnya. Sesuai dengan keberadaannya sebagai eksponen perempuan dan bagian dari civil society yang memiliki jumlah anggota lebih dari 12 juta yang tersebar di seluruh Indonesia, organisasi ini memiliki 33 wilayah, 516 cabang di tingkat kabupaten/kota, 4.750 anak cabang di tingkatan kecamatan serta lebih 26 ribuan ranting di tingkatan desa atau kelurahan. Bahkan di beberapa cabang sudah mengembangkan di tingkat anak ranting. Dalam mewujudkan tujuannya, Muslimat NU telah membina kurang lebih 9.800 taman kanak-kanak dan Roudhotul Athfal, 14.350 taman pendidikan al-Quran dan 4.600 pendidikan anak usia dini, 103 pusat pelayanan kesehatan, 106 panti asuhan, 10 asrama putri, 10 panti jompo, 59.956 majlis ta'lim, koperasi an-nisa yang sudah berbadan hukum terdiri dari 1 induk koperasi, 9 koperasi sekunder, 162 koperasi primer yang berbadan hukum, 355 TPK (tempat pelayanan koperasi), 146 kelompok bimbingan ibadah haji $(\mathrm{KBIH})$ dan 8 balai latihan kerja (BLK). ${ }^{20}$

\section{Kesimpulan}

Status otonomi Muslimat ini Muslimat mengatur dan melaksanakan kegiatan-kegiatan yang bertujuan meningkatkan peranan organisasi dalam membina para anggotanya dan menggiatkan organisasi dalam pengabdiannya kepada negara. Keberadaan lembaga-lembaga Wanita Islam (muslimat) yang independen akan menjadi faktor penting yang mempengaruhi bekerjanya hukum, baik sebagai alat kontrol sosial maupun alat rekayasa perubahan sosial (social engineering).

Hukum disini berkedudukan sebagai kaidah yang bermuatan pesan imperatif kepada masyarak at agar tunduk (patuh) terhadap peraturan perundang- undangan yang berlaku. Mengingat bahwa hukum sebagai alat kekuasan politik, maka penting bagi lembaga-lembaga Islam untuk melakukan pemberdayaan keadilan hukum demi tercapainya kehidupan masyarakat yang sejahtera dan Islami.

Muslimat NU melihat perlu ada modal keunggulan komparatif yang dimiliki para Muslimah yakni modal 
sosial, modal persatuan, modal untuk menjadi umat terbaik, modal sosial, dan modal pemikiran.Prinsip sosial yang harus dipegang Muslimat adalah sikap moderat, seimbang, toleransi, dan loyalitas tegak lurus.

Catatan kaki:

${ }^{1}$ M. C. Rickles, Sejarah Indonesia Modern 1200-2004, (Jakarta: Serambi Ilmu Semesta, 2005), cet. Ke-3, h.369.

${ }^{2}$ Sejak kelahirannya di tahun 1926, NU adalah organisasi yang anggotanya hanyalah kaum laki-laki belaka.Para ulama NU saat itu masih berpendapat bahwa wanita belum masanya aktif di organisasi.

3Organisasi Muslimat Nahdlatul Ulama ini yang semula adalah bagian dari organisasi Nahdlatul Ulama dengan nama Nahdlatul Ulama Muslimat (NUM). Muslimat berdiri atas prakarsa kaum perempuan Nahdlatul Ulama yang ingin memajukan perempuan dalam berbagai bidang dengan tetap berprinsip pada ajaran Islam.

4http://www.mwcnujepara.org/sejarah-muslimat-nu.h...tml diakses pada 2 Juni 2016.

${ }^{6}$ Sejarah Nahdlatul Ulama

7KOWANI, Sejarah Setengah Abad Pergerakan Wanita Indonesia (Jakarta: PN BalaiPustaka, 1978) h.341

8 Fathurin Zen, NU Politik Analisis Wacana (Yogyakarta:LKIS, 2004), h.15.

9 Mayling Oey Gardiner, Perempuan Indonesia Dulu dan Kini, (Jakarta:PT Gramedia Pustaka Utama, 1996). h.341.

10Pimpinan Pusat Muslimat Nahdlatul Ulama, Anggaran Dasar danAnggaran Rumah Tangga Muslimat NU, h. 8-9.

${ }^{11}$ Laporan Pertanggungjawaban Pimpinan Pusat Muslimat NU Masa Bakti 20062011, disampaikan pada Kongres XVI MUSLIMAT NU diAsrama Haji Bandar Lampung 13-18 Juli 2011., h. 7

${ }^{12}$ Pada Muktamar NU XIX, 28 Mei 1952 di Palembang, NOM menjadi badan otonom dari NU dengan nama baru Muslimat NU.

${ }^{13}$ A. Abd.MuchitMuzadi, NU dalam Perspektif Sejarah dan Ajaran, (Surabaya: Khalista, 2007), h. 170-17.

${ }^{14}$ Dalam pertemuan tersebut, secara khusus, Khofifah dan JK juga mendiskusikan sejumlah persoalan di Jawa Timur. Mulai pengentasan kemiskinan hingga masalah industrialisasi garam di Pulau Madura. "Kami mendiskusikan soal, terutama dari berbagai survei, masyarakat berharap bahwa pemimpin Jawa Timur bisa lebih cepat menuntaskan kemiskinan. Itu kita bahas, kebetulan ada Pak Bambang (Sekretaris Eksekutif Tim Nasional Percepatan Penanggulangan Kemiskinan/TNP2K). 
${ }^{15} 5$ Srikandi Muslimat NU Terpilih. Jadi Kepala Daerah 2018, Kader Muslimat NU yang sukses di Pilkada, selain Khofifah, yakni Nyai Hj Munjidah Wahab (bupati Jombang terpilih), Dra Hj Umi Azizah (bupati Tegal terpilih), Hj Ita Puspita Sari (wali kota Mojokerto terpilih), Hj Ana Mu'awanah... (bupati Bojonegoro terpilih) serta Hj Lilik Muhibah, MpdI (wakil wali kota Kediri (pen.)

${ }^{16}$ Muslimat Luncurkan Buku 70 Tahun Kiprah dan Karya Perempuan NU,Sabtu, 26 November 2016.

17 Tangerang Selatan, NU Online, Jumat, 20 Juli 2018 15:30 Nasional.

${ }^{18}$ Pemisahan sampah dapat membuat pengelolaan sampah lebih efisien," ujar Ariza dalam kegiatan pertemuan paguyuban bank sampah... binaan BLK Muslimat NU, Kamis (19/7) di Pusdiklat Muslimat NU Pondok Cabe, Tangerang Selatan, Banten.

${ }^{19}$ REPUBLIKA, Kamis 24 November 2016

${ }^{20}$ Laporan Pertanggungjawaban Pimpinan Pusat Muslimat NU Masa Bakti 20062011, disampaikan pada Kongres XVI MUSLIMAT NU diAsrama H...aji Bandar Lampung 13-18 Juli 2011., h 7.

\section{Daftar Pustaka}

A. Abd.Muchit Muzadi, NU dalam Perspektif Sejarah dan Ajaran, (Surabaya: Khalista, 2007), h. 170-17.

Fathurin Zen, NU Politik Analisis Wacana (Yogyakarta:LKIS, 2004), h.15.

KOWANI, Sejarah Setengah Abad Pergerakan Wanita Indonesia (Jakarta: PN Balai Pustaka, 1978) h.341

Laporan Pertanggungjawaban Pimpinan Pusat Muslimat NU Masa Bakti 20062011, disampaikan pada Kongres XVI MUSLIMAT NU diAsrama Haji Bandar Lampung 13-18 Juli 2011., h. 7

Mayling Oey Gardiner, Perempuan Indonesia Dulu dan Kini, (Jakarta:PT Gramedia Pustaka Utama, 1996). h.341.

M. C. Rickles, Sejarah... Indonesia Modern 1200-2004, (Jakarta: Serambi Ilmu Semesta, 2005), cet. Ke-3, h.369.

Muktamar NU XIX, 28 Mei 1952 di Palembang, NOM menjadi badan otonom dari NU dengan nama baru Muslimat NU.

Muslimat Luncurkan Buku 70 Tahun Kiprah dan Karya Perempuan NU,Sabtu, 26 November 2016

Pimpinan Pusat Muslimat Nahdlatul Ulama, Anggaran Dasar danAnggaran Rumah Tangga Muslimat NU, h. 8-9.

Tangerang Selatan, NU Online, Jumat, 20 Juli 2018 15:30 Nasional

Laporan Pertanggungjawaban Pimpinan Pusat Muslimat NU Masa Bakti 20062011, disampaikan pada Kongres XVI MUSLIMAT NU diAsrama H...aji Bandar Lampung 13-18 Juli 2011., h. 7.

http://www.mwcnujepara.org/sejarah...-muslimat-nu.h...tml diaksespada 2Juni 2016 REPUBLIKA, Kamis 24 November 2016 